\title{
Staffing And EEO Laws: A Human Resource Management Case Study
}

\author{
Arthur K. Fischer, Pittsburg State University, USA
}

\begin{abstract}
An HRM case dealing with problems and issues encountered as a company seeks to follow Equal

Employment Opportunity laws during the staffing process.
\end{abstract}

Keywords: HRM case, equal employment opportunity, staffing.

\section{INTRODUCTION}

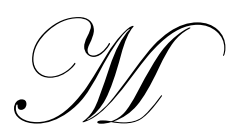

idwest Education, Inc. is a major supplier of educational materials for the United States. The company focus is on learning tools and systems for use in technology, science and business classrooms. In addition, it develops and provides books, manuals, videos, software and hardware used in the fields of technology education, instructional development and business applications.

The company has its headquarters and primary manufacturing plant in a major Midwest community. In addition, the Creative Development offices are located in Massachusetts and California. Transportation, Service and Maintenance facilities are headquartered out of Texas, with major branches in Baltimore and Phoenix.

The three main divisions exemplify three different strategies: cost-reduction, quality enhancement, and innovation (as discussed by Schuler and Jackson, 1987).

Transportation, Service and Maintenance. The primary strategy of the Transportation, Service and Maintenance Division is cost-reduction. Midwest Education, Inc. has long been known for providing service and maintenance programs which are very reasonably priced.

Manufacturing. The primary strategy of the Manufacturing Division is quality enhancement. Midwest education, Inc. has an enviable history of providing the highest quality products which have been adopted by first-rate schools and corporate training programs.

Creative Development. The primary strategy of the Creative Development Division is innovation. Midwest Education, Inc. is widely known for providing truly cutting edge teaching materials which always mirror the latest techniques and processes.

\section{COMPANY HISTORY}

Midwest Education was started by Henry and Mary Dalton in 1975. Dr. Henry Dalton was an industrial arts teacher before he got his MBA and went on to get his Ph.D. in Technology Education. Mary was a software developer who also taught business seminars. At that time a new wave of emerging technology was beginning to alter the way people learn and communicate. By developing Midwest Education, Inc. the Daltons began work in an exciting new field. They found a vast market for quality tools that educated people on how to use all the new technology. Dr. and Mrs. Dalton are in semi-retirement now and travel extensively, but remain major shareholders in the business. They personally hired the CEO when they went into semi-retirement.

The company started with about fifty employees, but has grown consistently and now has a total of 416 employees within its three major divisions: 158 employees work in the Manufacturing Division, 123 work in the 
Creative Development Division and 135 work in the Transportation, Service and Maintenance Division. There are also 71 employees working at the headquarters in Kansas City (including the corporate staff).

At the beginning on the 1990s it became apparent that international business was becoming the rule rather than the exception. The company went international in 1994 and now is exporting to three European, two Latin American, and two Pacific Rim countries. The Global Operations Division is located within the headquarters.

\section{HEADQUARTERS}

The corporate headquarters are in Kansas City. The CEO of Midwest Education, Inc. is Judith Lund. Ms Lund was hired by the Daltons in 1994 when they decided to take a less active role in the company while remaining major shareholders. Ms. Lund has an MBA in business management, and was previously the CEO of a small telecommunications company. In her previous position, Ms Lund had successfully steered the company out of financial difficulties by raising stock value. She had initiated a strong advertising campaign and had put the company 'in the black' for the first time in seven years.

The COO of Midwest Education, Inc. is Frank Rose. Frank has been with the company since 1989. Mr. Rose, a cousin of Dr. Dalton, had a successful career with an international business training group in California. His desire to move back to his home town of Kansas City came at a time when the Daltons were looking for a COO. He has worked out well for the company.

The Human Resources Department is also located at the headquarters. The Vice President for Human Resources is Lawrence Wilson. Mr. Wilson has a degree in industrial and organizational psychology and an MBA. He has been with the company for 11 years. He started out as a generalist and was promoted as he showed good judgment with hiring and earned his MBA at the same time.

Within the Human Resources Department there are four sections:

1. Staffing, the head of this section is Patrick Shew.

2. Compensation and benefits section, headed by Michael Martin.

3. Labor management relations section, headed by Keith Lane.

4. Training, career development and performance appraisal section, headed by Cynthia Burns.

There are also human resource specialists in each of the three divisions around the country.

\section{MANUFACTURING DIVISION}

The mission statement for the Manufacturing Division is:

"The aim of the Manufacturing Division of Midwest Education, Inc. is to continually improve the quality and strength of all our products. The superior products for which we have become world renowned will still be manufactured along with new and innovative products and ideas. We will work hard to keep quality high and cost down while supplying customers with the best possible products in the shortest possible time." The Manufacturing Division follows a strategy of quality enhancement.

The main manufacturing plant is located on the outskirts of Kansas City, not far from the company headquarters. The president of the Manufacturing Division is Max Thorn. Mr. Thorn has been with the company almost since its inception. He was one of the first employees hired by the Daltons. He started writing programs for the company and originally worked alongside the Daltons in interviewing and hiring many other employees.

The head of human resources for the Manufacturing Division is Janine Woods. She has a staff of five generalists who assist her in meeting HRM needs for the Manufacturing Division.

The Manufacturing Division used to be housed in the same building as the headquarters. As the business expanded and more room was needed, the division moved to the suburbs into a large factory site. There are 158 
employees in the Manufacturing Division. They are divided into ten teams, each team works at producing and packaging a specific product at a time. There are five supervisors who each supervise two teams: Doris Malone, John Fizer, Sandi Cross, Wendy Atchison, and Ian Carpenter.

The Manufacturing Division usually has a long lead time on orders and can anticipate what will be needed. The factory has flexible work areas that can be re-tooled and rearranged for the changeover from one product to another in less than four hours. The pay in this Division starts at $\$ 6.25 / \mathrm{hr}$ for production workers and has a full benefits package. Most employees seem happy with their work. Max Thorn is generally thought of as a good, easy-going man to work for.

\section{CREATIVE DEVELOPMENT DIVISION}

The mission statement for the Creative Development Division is:

"In the Creative Development Division of Midwest Education, Inc. we will strive to bring our customers the most innovative and cutting edge programs and products in the world. Our team of creative professionals is constantly working to improve, upgrade, and create the most useful products to bring to our customers." This division follows a strategy of innovation.

The Creative Development Division has two locations; a headquarters in California and a branch located in Massachusetts. The president of the Creative Development Division is Serena Tibaldo. Ms. Tibaldo recently joined the company. Previously she was a software developer for a large computer game producer. She has a bachelor's degree in business and a computer programming master's degree, and is doing very well at Midwest.

The head of human resources for the Creative Development Division is Amelia Chi, who is located at the California headquarters. Ms. Chi has a staff of five assistants. The head of the human resource section at the Massachusetts branch is Virginia Fox. Ms Fox has a staff of two assistants.

There are 90 people employed at the California plant and 38 at the Massachusetts location. The California location opened in 1980 and the Massachusetts branch was opened in 1993. In the 1970's and 1980's many computer software programmers moved to the west coast to be located in Silicon Valley. Most people hired by Midwest Education, Inc. transferred from wherever they lived to the California branch, with the company paying all relocation expenses. By 1990 some employees desired to live in the east. The Daltons decided it was time to expand the company and in doing so decided the next branch would be in the Massachusetts area. Most of the long time elected to remain California. The majority of recent hires are in Massachusetts.

\section{TRANSPORTATION, SERVICE AND MAINTENANCE DIVISION}

The mission statement for the Transportation, Service and Maintenance Division is:

"The Transportation, Service, and Maintenance Division is committed to providing the fastest and most cost effective way of safely shipping our product to our customers. No effort will be spared as we streamline and improve our fast and friendly service". The Transportation, Service and Maintenance Division follows a strategy of cost-reduction.

The Transportation, Service and Maintenance Division headquarters is located in San Antonio, Texas. There are major branches in Baltimore, Maryland and Phoenix, Arizona. The President of the Transportation, Service and Maintenance Division is Mark Derrick. Mr. Derrick is based in San Antonio. Mr. Derrick has been with Midwest Education, Inc. for 13 years. He personally hires the managers for the other branches in Maryland and Arizona.

The head of human resources for the Transportation, Service and Maintenance Division is Salvador Vasquez. Mr. Vasquez has a staff of five assistants. Mr. Vasquez appoints HR heads to the other branches. Often they are employees from San Antonio that he knows well and trusts. 
The Transportation, Service and Maintenance Division was originally based in Kansas City. As the company grew a decision was made to relocate the division to Texas. The other branches are newer, with Maryland opening in 1989 and Arizona in 1996. There are 55 employees in San Antonio, and 40 in each of the other two branches.

\section{SITUATION: STAFFING CASE}

\section{$\underline{\text { Part One }}$}

Two months ago Serena Tibaldo, head of the Creative Development Department, along with four other employees located in the California branch, were all fired after having been caught up in a scheme to embezzle money from MidWest Education. News of this reached the local papers and made the front pages. The decision to press charges on all of these was made, and the results of these charges are still pending.

In the mean time, Ms Lund (CEO) and Lawrence Wilson (the Vice President for Human Resources) needed to fill the vacant positions. The first task was to find an individual to take over Tibaldo's spot as head of the Department. In order to do this a meeting was held at the headquarters office in Kansas City. Ms. Lund, Mr Wilson, and Virginia Fox (head of human resources for the Massachusetts Creative Development Division) were all present. Through a very long discussion and deliberation they had narrowed down a list of candidates. Before they made a decision though, they needed to address some of their concerns. The first thing they needed to decide was if they were going to hire someone from within the company or someone who doesn't currently work for them. Another issue is that Serena Tibaldo was the first woman to ever hold the position as head of the Creative Development Department. The last eleven were male. Would it make a difference if they hired a male or a female? The following is a list of possible candidates the group has come up with:

Jose Garvic: Jose is currently working for a human development company in Mexico City that trains out-of-work people who are new on the job skills. He supervises approximately 30 people and is in charge of developing new programs for his department; the programs he created have been very innovative and have been used widely throughout his company. He is wanting to get out of Mexico and move to California to "live the good life" as he's said. Since he's been in his current position, his department has more than doubled its business. His first language is Spanish, but he does speak decent English. He has a degree in business management.

Robert McAdams: Robert recently retired and has become very bored with it. He's looking to get back into the business world. When he retired he was the CEO of a small technology company that developed educational tools for school districts. The tools they developed were new and had interesting ways to teach kids how to use computers. The size of his company tripled since he'd taken over and it continued to grow after he left. He has a degree in computer information systems and an MBA. He is a very fun and cheerful man, but sometimes this can distract him and others from their work. He is a natural leader, and people like to work for him.

Adam Street: Adam is currently a member of the Creative Development Department located in the Massachusetts branch. He has a degree in graphic design and an MBA. He is relatively new to the company and does not have much experience within the department. He's known as a very loyal and hard working individual. Others find him very easy to work with and can count on him for help whenever they need it. Projects that he works on are always turned in on time and are above and beyond what is expected. Adam was a 4.0 student at an Ivy League school when he received his undergraduate degree in software design, and will finish his masters' degree in computer science next month.

Ann Shore: Ann has a degree in economics and a degree in marketing. She recently worked for a company that was forced to declare bankruptcy. While there she had been a fast-tracker and had moved up the ranks very quickly. She held a parallel position to the one she is applying for when she was let go. The recommendations given by her former supervisor are outstanding. She seems to be a very brash and in-your-face type of person, but she knows what she wants and knows how to get it from her employees. This can make it stressful to work for her, but everything she works with turn out much better than projected. She has a slight speech impediment but has not let that stop her in the past. 
Wendy Atchinson: Wendy has been a member of the Manufacturing Division for the past 17 years. She has moved up through the ranks of this division, starting out as a member of the manufacturing team. She's now head supervisor for two of these teams. She's a very hard worker and her teams are always producing the highest quality products of the teams. Some workers occasionally find her difficult to work for because she is always pushing them to do better. She has a very strong sense of how to produce a quality product, and how to get the most out of her employees. She has a degree in management and a masters' degree in graphic design.

\section{Questions:}

1. Should the decision be made to hire someone from within the company, or someone new?

2. Who would you choose for the new head of the department and why?

3. Did you take into consideration whether or not to hire a female? If a female is not hired is there any discrimination?

\section{$\underline{\text { Part Two }}$}

(Now that the new head of the department had been hired) Amelia Chi, the head of the Human Resources Department for the Creative Development Department in California, could focus on hiring the four other positions that had been lost. In order to find possible candidates for these positions, ads were placed on Monster.com, as well as several other websites. E-mails were sent out to all qualified applicants who had applied to the department within the last six months. Amelia also went to the four local universities to recruit people who were graduating. With the ads placed online, the prior qualified applicants, and the college recruiting, nine qualified applicants were found. All were brought in and interviewed. Currently, the Creative Development Department's demographics for the California plant are as follows:

\begin{tabular}{|l|c|c|}
\hline & Male & Female \\
\hline White & 61 & 2 \\
\hline African American & 5 & 4 \\
\hline Hispanic & 9 & 0 \\
\hline Asian & 2 & 2 \\
\hline Age 40 and up & 11 & 9 \\
\hline College Graduates & 68 & 2 \\
\hline
\end{tabular}

The population demographics for similar California white-collar workers are as follows:

\begin{tabular}{|l|c|c|}
\hline & Male & Female \\
\hline White & $56 \%$ & $1 \%$ \\
\hline African American & $7 \%$ & $10 \%$ \\
\hline Hispanic & $15 \%$ & $1 \%$ \\
\hline Asian & $2 \%$ & $12 \%$ \\
\hline Age 40 and up & $14 \%$ & $73 \%$ \\
\hline College Graduates & $71 \%$ & $12 \%$ \\
\hline
\end{tabular}

Description of the nine qualified candidates interviewed:

Luis Springdale: Luis has worked as a freelance software developer for the past nine years. He has designed software used by several very large companies and has some great examples of the work that he has done. He has never worked for or with anyone before. All of his work has been on his own. He is looking for a hob because he wants to move into something with a little more stability. He does have some new and creative ideas. He is a white male, and is 34 years old. He does not have a degree. 
Lisa Muñoz: Lisa is a 22 year old Hispanic just out of college. She received her degree in marketing just three months ago. She had a GPA of 3.8 and was the head of several organizations at her school. She has very little experience, but has had an internship with a company very similar to MidWest Education. In her interview she had several great ideas that impressed Mrs. Chi.

Gloria YuShan: Gloria is a 29 year old Chinese woman who received her degree in management in California. After she graduated she moved back to China and worked there for her family business for the past six years. She has recently moved back to the States and is looking for a position that will help her progress up a corporate ladder. Little is known about her work habits.

Martin Hallacy: Martin is a 25 year old white male who just received his degree in Information Technology from a local university. His GPA was 3.2 and he was the president of his fraternity. He doesn't have any relevant work experience, but gave an excellent interview. He is a member of the California National Guard.

Thomas Decker: Thomas is a 45 year old African American with all kinds of experience. He doesn't have a college degree. He has an amazing set of references and everything said about him has been positive. In his interview he expressed a desire to work on something new and exciting.

Cora Hurt: Cora is a 58 year old woman who has been in and out of work all of her life. She has a degree in business administration and has held numerous different positions with different companies. When she was asked why she did not stay with one company for more than about five years at a time her response was family reasons. All of her references confirm that she is a nice lady and a hard worker.

Henon Heftson: Henon is a 33 year old Asian man with a degree in graphic design and a degree in management. He has never worked in the United States, but received both of his degrees here. He speaks very good English and has great communication skills. He seems very eager to work at MidWest Education.

Jordan Walker: Jordan is a 29 year old white make with a degree in economics. He has been working in the creative development department for an automobile manufacturer for the past six years and is wanting a change. He loves coming up with new ideas and has very relative work experience.

Juan Ramirez: Juan is a 24 year old Hispanic make who just received his degree in general studies. He fought his way to put himself through school, and was the first in his family to finish. His GP was only a 2.7, but he worked as many as three jobs at a time in order to afford to go to school. He is a very hard worker and a very determined individual.

\section{Questions:}

1. How effective were Amelia Chi's techniques in recruiting new employees?

2. Is there any current discrimination among the employees who work in the department compared to the local demographics?

3. Which four of the nine employees would you select and why?

\section{AUTHOR INFORMATION}

Dr. Art Fischer is a University Professor in the Department of Management and Marketing at Pittsburg State University. He is a FELLOW with the American College of Healthcare Executives, and is a retired healthcare executive. 